\title{
THE TUNISIAN CONSTITUTIONAL TRANSITION AND DEBATES: ISLAM, WOMEN AND OTHER ACTORS IN THE WAKE OF THE POST JASMINE REVOLUTION
}

\begin{abstract}
Ashraf Booley ${ }^{1}$
ABSTRACT

The Arab uprising in Tunisia, dubbed the Jasmine Revolution began in 2010, protesting against unemployment, corruption, injustice and the absence of basic freedoms. The Jasmine Revolution ousted Ben Ali, the then president who was in power for more than three decades in 2011. Post Jasmine Revolution saw Tunisia making commendable strides in its transition towards a new all-inclusive democratic political order. However, the transition process has not been without obstacles which could have had the effect of derailing the transition process, such as the assassination of activists Chokri Belaïd and Mohamed Brami, the role and place of Islam, the inclusion of women in the political transition and the most popular Islamic party Ennahda with its rumours of transforming Tunisia into an Islamic state were cause for great concern for all. However, despite these concerns, Tunisia's new constitutional text is considered to be a radical departure from its previous constitutional texts. After the drafting of various drafts, the 2014 constitutional text has attained the status in the Middle Eastern And North African Region MENA Region as being the most liberal compared to other countries in
\end{abstract}

\footnotetext{
Senior Lecturer, Private Law Department, University of the Western Cape,
} Bellville, abooley@uwc.ac.za 
the Mena Region. The 2014 constitutional provisions protect civil liberties, separates legislative, executive and judicial powers, guaranteeing women parity in political institutions, and declares that Islam is the country's official religion while at the same time protecting religious freedom for all. An important facet is the homogeneity of Tunisian society - which although has some divisions, did not suffer fragmentation along religious, political, cultural or ethnic lines, as is the case in other Muslim states. This was accomplished by including all actors not only political parties, women's groups and activists, religious activists, but also the various unions which represented the working class in Tunisia. The outcome was nothing short of being miraculous, bearing in mind the chaos that engulfed Tunisia during this period. One could argue that Tunisian listened to its people and advice of all, thereby minimising a terrible outcome.

Keywords: Jasmine revolution, Islam, women, constitution, debates

\section{INTRODUCTION}

The period of December 2010 and January 2011,2 saw Tunisia being catapulted onto the world stage, as Tunisian's flooded the streets in protest against unemployment, corruption, injustice, exclusion and the absence of basic freedoms. ${ }^{3}$ The protest managed to oust the then President Zine Abidine Ben Ali, who was already in power for the past three decades. ${ }^{4}$ Although,

2 It has been commonly acknowledged that the act of self-immolation on 17 December 2010 of Mohamed Bouazizi sparked the wave of spontaneous protest. The root of the protest were decades of repression, injustice, exclusion and the absence of basic rights. Tunisians across the divide identified with the act of Mohamed Bouazizi. It is believed "Mohamed Bouazizi did not self-immolate to as ask for bread, but for the dignity to work which would in turn give him bread". The protests began in the marginalised regions of Sidi Bouzid and Kassrine, in central and west central Tunisia.

3 Zoglin, 'Tunisia at a Crossroads: Drafting a New Constitution,' American Society of International Law, vol. 17, no. 18 (2013), 1-19.

4 Zine el Abidine Ben Ali ruled Tunisia form November 1987, following the removal of the founder of the Tunisian Republic, Habib Bourguiba, through what was a so called "medical coup". The subjugation of human rights by the ousted president and his family as well as his entourage lay at the epicentre of the problem. To maintain a monopoly on political and economic existence the then authorities denied Tunisians there economic, social, civil and political rights. The indivisibility of rights became apparent from the very start of the protests. 
for the past 50 years or so Tunisian lives were controlled by an authoritarian government under different presidents. The effect of the Jasmine revolution, created an atmosphere which saw Tunisians taking advantage of by setting in motion a process of adopting a new constitution and addressing the lacuna of fundamental and basic human rights. ${ }^{5}$

Amongst other important issues, one issue that was contentious was what would be the role of Islam in the process of going forward. The role of Islam has always been and will be a prominent feature not only in Tunisia, but in countries, where the population adhere to the Islamic faith. Not surprisingly, after attaining independence, Islam has been declared in all constitutional texts as the "religion of the State" and the Arabic language became the official language. ${ }^{6}$ Of interest, was article 38, which states that the -"The President of the Republic is the Head of State. His religion shall be Islam". These constitutional provisions of earlier text provides the importance of Islam in Tunisia. The role of Islam in Tunisia, will become evident as the article progresses.

This has become evident in Tunisia that Muslim communities observe Islam in their daily lives, as a faith and a way of life which at times is difficult to separate. ${ }^{8}$ Tunisia has been exposed to the so-called Arabo-Islamic influence since the $7^{\text {th }}$ century and its national identity has been manifested by this civilization and was used as an instrument (there were other organizations that assisted) in uniting the country in its struggle for independence against the French. $^{9}$

Inferences may be drawn from the above, that the role of Islam would always attract serious debates, in the process of going forward. Therefore, the debates that emanated from the Jasmin revolution came as no surprise to those who observed the transitional process. There were debates relating to the drafting of a new constitution, for example, various ideological divisions between conservative/Islamist and secularist/modernist proponents as well as a more technical opposition between scholars/experts, who argue

5 Proctor \& Moussa, 'The Tunisian Constituent Assembly's By-laws: A Brief Analysis,' http://www.ndi.org, accessed on 30 September 2018.

6 See The Constitution of Tunisia 1959, Article 1 Tunisia is a free, independent and sovereign state. Its religion is Islam, its language is Arabic and its type of government is the Republic.

7 The Constitution of Tunisia 1959.

8 Suliman, 'The First Political Systems in the Independent Maghrib: A Comparative Study,' http://www.iua.edu.sd, accessed on 20 September 2018.

9 Suliman, 'The First Political Systems in the Independent Maghrib: A Comparative Study.' 
for a constitutional text, containing universal guidelines and human rights proponents who advocated for a detailed constitution that meticulously puts forward human rights provisions, citing the South African constitution and its various provisions, especially, Chapter two, its Bill of Rights. ${ }^{10}$

Part A- looks at the position and role of Islam and women, during the various period of Tunisia. For example, during the pre and post French Protectorate, the period of Tunisia's first president, and the presidency of Ben Ali. Part B - describes the constitutional process, participants and dealing with central areas of disagreements and agreements during the constitutional transitional process. This will not be a comprehensive evaluation of all the aspects of the constitutional transitional process that took place in Tunisia.

\section{PART A - A HISTORICAL PERSPECTIVE OF TUNISIA, ISLAM AND WOMEN}

Tunisia was conquered by the advancing forces of Islam during the first half of the $7^{\text {th }}$ century when an important garrison was established at Qayrawan in the former Roman province of Africa.${ }^{11}$ A large part of the Tunisian population converted to Islam. ${ }^{12}$ The type of Islam that was developed in Tunisia was grounded in Shariah as interpreted by the more dominant Mālikī and to a

10 Shaqoura \& Kristiansen, 'Islam and Human Rights: The Constitutional Debate in Tunisia,' The Danish Institute for Human Rights, http:// www.humanrights.dk, accessed on 16 October 2018. The Republic of South Africa, Constitution 1996, Chapter 2, Bill of Rights.

11 Hourani, A History of the Arab Peoples (United Kingdom: Farber \& Farber, 2013), 1-640. The Shariah is the whole body of law, encompassing the teachings of various schools of law, the al-Qur'ān, the Sunnah, and legal precedent established in individual cases. Islam is a monotheistic religion which sharers its roots and some of its core beliefs with Judaism and Christianity. It could be argued that the al-Qur'ān was revealed at a time and place in history when patriarchal values reigned supreme and its laws in a large part tempered and relieved some of the most egregious excesses which then subsisted by creating new regulations for society and modifying customary practices. There are five major schools of Islamic law: four Sunni and one Shia. The difference between the schools, centre' s on the difference of interpretation of some Quranic verses, disagreements among religious scholars on the authenticity of some hadith, dissenting with regard to the weight to be given to some legal sources, and differences in opinion as to what is required when faced with novel practical situations.

12 Morse \& Sayeh, 'Tunisia: Marriage, Divorce, and Foreign Recognition,' Family Law Quarterly, vol. 29, no. 3 (1995): 701-720. 
lesser extent the Hanafĩ religious schools of thought found in Sunni Islam. ${ }^{13}$ In addition, the Arabic language spread simultaneously with Islam as a spoken word in its various dialects influenced by the previous indigenous languages whose unity was preserved by the al-Qur'ann, the holy scriptures of Islam, revealed to Prophet Muhammad $[\mathrm{PBUH}] .{ }^{14}$ During the second half of the 7 th century North Africa was engulfed by Muslim Arabs and the result was that the roots of Islam became embedded as such. ${ }^{15}$ As a result of such influences Islam in Tunisia has a played a basic and fundamental role in shaping the country, as a religion, a culture, identity and a source of law (especially its family law). ${ }^{16}$

A case in point is the establishment of the now Al-Zaytuna University. ${ }^{17}$ Founded as a madrasah (religious learning school) in the early $7^{\text {th }}-8^{\text {th }}$ century, the school flourished during the Middle Ages and evolved into a religious university, along with theology, although focussing mainly the teaching of the al-Qur' $\bar{a} n$, the university also taught jurisprudence, history, grammar, science and medicine. ${ }^{18}$ Alongside Cairo's Al-Azhar Univeristy, the Al-Zaytuna was considered to be on par in terms of being recognised as a leading Islamic educational institute in the MENA Region, although this is debated amongst various scholars. ${ }^{19}$ In Tunisia, public habous (a type of ownership, which

13 Charrad MM, 'Policy Shifts: State, Islam, and Gender in Tunisia, 1930s-1990s,' Social Politics (1997): 284-319.

14 Charrad MM, 'Policy Shifts: State, Islam, and Gender in Tunisia, 1930s-1990s,' 284-319. It is customary for the words Peace and Blessings Upon Him [PBUH] to follow.

15 Islam is part of more than one billion people's lives. Its legacy spans more than fourteen centuries, and today Islam is the fastest growing religion on Earth. The Islamic faith has contributed to a multiplicity of cultures, languages, and peoples, and has taken part in every major human endeavour, from anatomy to philosophy. For all of its varieties, one characteristic shared by all followers of the Islamic creed is an adherence to a divinely inspired law-an Islamic law, the Shariah.

16 Proctor \& Moussa, 'The Tunisian Constituent Assembly's By-laws: A Brief Analysis.' During the colonial period, women were marginalized and secluded, there was not much access to education, economic activity was largely confined to the domain of the home, wearing of the veil was practiced. In addition, public participation in public life was reduced to a minimum.

17 Ez-Zitouna Mosque or Ezzitouna Mosque or Mosque of El-Zituna (Arabic: الزيتونة, literally meaning the Mosque of Olive) one of two major mosques in Tunis, Tunisia.

18 Croitoru, 'Controversy Surrounding the Al-Zaytuna in Tunis: The Ambivalent Revival of Islamic Traditions,' http://en.qatana.de, accessed on 17 January 2019.

19 Croitoru, 'Controversy Surrounding the Al-Zaytuna in Tunis: The Ambivalent Revival of Islamic Traditions.' 
can be public, private or mixed) was introduced for the funding of religious organizations and public institutions such as schools, mosques and hospitals. ${ }^{20}$ The property habous or waqf is an institution entirely original, invented by Islamic law. ${ }^{21}$ The legal institutions are described as property waqf, mainly in the laws of the Middle East and as goods and property habous in the Maghreb region. ${ }^{22}$

Tunisia's early history reveals, a reformist movement led by Arab and Muslim scholars arguing for reforms of the existing legal systems seen by the movement as inferior to Western legal systems. In 1857 Ahmed Bey's successor, Mohamed Bey (1855-59), issued the so-called Fundamental Pact, ${ }^{23}$ which spelled out the principles regulating relations between the Bey and his subjects and foreigners residing in Tunisia. The document, dictated to the beylicate by the French consul in Tunis, also allowed foreigners to own property in Tunisia and guaranteed them equal protection under the law. The Fundamental Pact paved the way for the appointment of Kherredin Pasha, a Circassian Mamluk with long service in Tunisia and the son-in-law of Mustafa Khaznader, to draw up a constitution. ${ }^{24}$

\section{ISLAM, WOMEN AND THE FRENCH PROTECTORATE}

The French occupied North Africa in later part of the 1800's, establishing a protectorate from 1881-1956 by way of a treaty, rather than outright conquest

20 Habous Encyclopedia.com, http://www.encyclopedia.com, accessed on 5 January 2019. It has been recorded in a hadīth that 'Umar Ibn al-Khațāa asked Prophet Muhammad [PBUH], what, could he do with his lad to please Allah SWT. The Prophet declared: "Immobilize it so that it cannot be sold, donated, inherited and distributed to the poor". 'Umar Ibn al-Khațāa followed this advice and declared that the land in question could not be subject, in the future, of a sale or donation. In other words, it is well placed out of the sphere of commerce and safe from any alienation because of its purpose of general interest.

21 Khalfoune T., 'Le Harbous le domaine public et le trust,' Revue internationale de droit comparé, vol. 57, no. 2 (2005): 441-470.

22 Khalfoune T., 'Le Harbous le domaine public et le trust,' 441-470.

23 The Fundamental Pact ('ahd al-aman in Arabic) was issued in Tunis in 1857. It was legally adopted as the country's constitution in 1861 , at which point it became the first written constitution in the Arab World.

24 The Constitution of Tunisia 1861. 
by the French. ${ }^{25}$ Tunisia retained its indigenous system of government with the Bey holding power. Although, commercial and legal infrastructures of Tunisia was appropriated by the French, French citizens residing in Tunisia falling under the French statut personnel, the laws governing the personal status of Tunisian nationals continued to be Muslim Laws which had taken root. ${ }^{26}$

Unlike most Arab countries, Tunisia boasted a long and distinguished history, which reflected a tradition of physical and social unity. ${ }^{27}$ Before Tunisia fell under the protectorate of the French, it celebrated a legacy of geographical continuity, religious and linguistic homogeneity including comparative social solidarity. ${ }^{28}$ As Micaud, observed that, "when the French occupation started in 1881 , Tunisia had long been a unified country, possessing all the institutions of a viable society - it did not have to discover that it was a state". ${ }^{29}$ Islam became inviolate in the family law sphere. ${ }^{30}$ Charrad, a legal scholar argues that Islam

25 Tunisia - The French Protectorate (1881-1956), http://www.britannica.com, accessed on 5 January 2019. Officially, the Bey remained an absolute monarchy. Tunisian ministers were still appointed government structures preserved and Tunisian's continued to be subjects of the Bey. The French did not dismantle existing institutions, maintaining instead the degree of self-rule established by the Turkish monarchs, referred to as the Beys.

26 Morse \& Sayeh, 'Tunisia: Marriage, Divorce, and Foreign Recognition,' 701-720.

27 Entilis, 'Reformist Ideaology in the Arab World: The Case of Tunisia and Lebanon,' The Review of Politics, vol. 37, no. 4 (1957): 526.

28 Entilis, 'Reformist Ideaology in the Arab World: The Case of Tunisia and Lebanon,' 526.

29 Micaud, 'Tunisia's Foreign Policy: Independence and Development,' Africa Today: African Non-Alignment and Foreign Policies, vol. 15, no. 6 (1968-1969): 12-15.

30 Shariah is an Arabic word that means the "path to be followed", referring to a number of legal injunctions. The intricacies of ethical, moral and religious raw materials derived from the primary sources of Islam, were given shape and direction by Islamic jurists during the second and third centuries of the Islamic calendar. The Sunni Muslims trace their jurisprudential descent through the first four 'Umayyad caliphs and was principally the work of four jurists; Abū Hanīfah, Mālik Ibn Ānas, Muḥammad Ibn Idris al-Shāfi'ī and Ahmad Ḥanbāl. The Imams, or founders developed separate schools during the great period of theological interpretation that occurred after the demise of Muhammad. The various schools have been named after their founders, namely, Hanafīi, Mālikī, Shāfi ‘ī and Hanbalī. No one school of thought enjoys universal dominance, however, and in Morocco and Tunisia, for example, the Mālikī school is the most influential, whereas in Egypt, the Hanafĩ school appears to be the most popular. There are other schools found in Sunni Islam, which are less dominant. 
came into a society where kin groups functioned as corporate units in which males (fathers, sons and husbands) possessed control over women (mothers, daughters and wives). ${ }^{31}$

The Tunisian population under colonial rule believed that being Tunisian included having allegiance to Islam. ${ }^{32}$ Therefore, Tunisian's viewed Islam as a cornerstone of their separate identity from the French..$^{33}$ As with any colonised country interference with its religious laws had the potential to erupt into civil disobedience. Therefore, the French did not intervene and Islam was left intact as well as its family law with all its restrictions, and served as a point of distinction between Tunisians and the French. Although the French limited its interference in Islamic domain, the French changed other laws, such as, property and contract law. ${ }^{34}$

In the 1920s and 1930s, as the struggle intensified, voices surfaced for greater gender equality. ${ }^{35}$ Only a limited amount of women publicly denounced their confinement, illiteracy, subservient position in the family and imposing marriages, although their calls went relatively unanswered. ${ }^{36}$ In the late forties, some prominent Tunisian jurists thought that a fusion of the Mālikī and Hanafī religious schools of thought a codified code of personal status could be created, conforming with social changes in the country. ${ }^{37}$ These jurists prepared a comparative account of the law as it stood under the two religious schools of

31 Charrad MM, 'Policy Shifts: State, Islam, and Gender in Tunisia, 1930s-1990s,' 284-319.

32 Charrad MM, 'Policy Shifts: State, Islam, and Gender in Tunisia, 1930s-1990s,' 284-319.

33 Charrad MM, 'Policy Shifts: State, Islam, and Gender in Tunisia, 1930s-1990s,' 284-319.

34 The reasons included economic and political considerations. Economic exploitation, which was primarily interested the French, made changes in commercial law critical, whereas it did not require similar changes in Islamic law. Other colonies such as Algeria experienced more extensive settlements of individual farmers with small holdings.

35 Salem, 'Tunisia,' www.freedomhouse.org, accessed on 3 January 2019.

36 The first women's associations, the Tunisian Women's Islamic Union, was created in 1936. Women went on to participate in the fight for independence, and slowly affirmed their place in society. By 1956, nationalist leader Habib Bourguiba's speeches were emphasizing that the development of the country depended on the participation of everyone, women and men alike.

37 Chusanayaini, 'Dynamics of Tunisian Polygamy Law in Gender Perspective,' media.netili.com, accessed on 2 May 2020. 
thought and published under the title Laihat Majallat al-Ahkam al Syar 'iyyah (Draft Law Islamic Law). ${ }^{38}$

During the fight for independence, Bourguiba, was aware of the place, of Islam and women which was by that time firmly entrenched in Tunisian society. Realising that, Bourguiba, saw Islam and women's organizations and struggles as a powerful instrument for mobilising the masses, for example, he used Islamic institutions and symbols and the calls of women (relating to gender equality as blocks to build a strong following. ${ }^{39}$

\section{ISLAM, WOMEN AND HABIB BOURGUIBA}

In the early 1960 's, Bourguiba in line with his secularists policies closed the AlZaytuna mosque, one the leading traditional religious institutions in Tunisia. ${ }^{40}$ Henceforth, Islam, as a subject was taught at the neighbouring Al-Zaytuna University, named after the mosque, under severe supervision of the newly enacted state. ${ }^{41}$ It could be argued, that this action was central to long term implications in levelling the field when it came to interpretation of Tunisia's Islamic law. ${ }^{42}$ The ideology was that the modern university would produce scholars in the fields of humanities and social sciences who would focus on

38 Later, the government set up a committee under the supervision by the Shaik of Islam of the country, Muhammad al-Ja'it, to officially draft the code. Shaik of the Zaytunah University, Tahir bin 'Ashur also participated in the committee's deliberations. The committee submitted to the government the draft of the code of personal status. It was eventually enacted under the title Majallat al-Ahwal alSyakhsiyyah (Code of Personal Statutes) in 1956-1957.

39 Bourguiba's PSD party held meetings in mosques and zawiyas (meeting places or corners) and urged people to pray five times a day for national martyrs. Bourguiba's title al mujahid al akbar (the great warrior) held a popular mystique as he led the people forward in jihād (holy war) against the French.

40 Having been declared president for life by the national legislature in 1975, the aging Supreme Combatant presides over a nation that is in the process of cultural, social, economic, and political transition. Founded as a madrasah (Islamic learning school) as early as the beginning of the $8^{\text {th }}$ century, the school developed in the late Middle Ages into a religious university. The literal meaning of Al-Zaytuna is the mosque of Olive.

41 Croitoru, 'Controversy Surrounding the Al-Zaytuna in Tunis: The Ambivalent Revival of Islamic Traditions.'

42 Tais, 'Islamic Perspectives in Post-revolutionary Tunisia,' Journal of Religion \& Society, vol. 17 (2015): 1-12. 
various elements of Islam, which would go beyond the limits of the more traditional perspectives. ${ }^{43}$ Alongside Cairo's prestigious Al-Azhar University, the Al-Zaytuna University was considered to be on par when it came to Islamic education, although this is debated amongst scholars. ${ }^{44}$

In the early 1960's Bourguiba in line with his secularists policies closed the Al- Zaytuna mosque. ${ }^{45}$ Henceforth, Islam, as a subject was taught at the neighbouring Al-Zaytuna University, named after the mosque, under severe supervision and restrictions of the newly enacted republican state. ${ }^{46}$ Bourguiba, aims for Tunisia was the creation of a modern state according to the ideals of the French revolution. ${ }^{47}$ Themes such as progress, rationality and human dignity were titled Bourguibism (a term echoed by French journalists to describe Bourguiba's philosophy). ${ }^{48}$ Bourguiba did not address himself as a secular reformer as the then Kemal Ataturk of Turkey. Instead, he portrayed himself as a modernist reformer he said "our concern" is to return to religion to its dynamic quality. ${ }^{49}$ Being sensitive to the Islamic character of the country, he was well aware that religious custom and belief was the foundation of Muslims in Tunisia. ${ }^{50}$ During the Bourguiba period the role of Islam played a powerful political tool and as such was used as a legitimate factor to mobilise the masses. ${ }^{51}$

The most controversial component of modernity - and the one which underpins the workings of Bourguiba ${ }^{52}$ on an internal level - has been changes

43 Tais, 'Islamic Perspectives in Post-revolutionary Tunisia,' 1-12.

Both institutions are well known for its moderate line and famous graduates such as the Arab historian Ibn Khaldun.

45 Founded as a madrasah (Islamic learning school) as early as the beginning of the $8^{\text {th }}$ century, the school developed in the late Middle Ages into a religious university. The literal meaning of Al-Zaytuna is the mosque of Olive.

46 Croitoru, 'Controversy Surrounding the Al-Zaytuna in Tunis: The Ambivalent Revival of Islamic Traditions.'

47 Boulby, 'The Islamic Challenge: Tunisia since Independence,' Third World Quaterly, vol. 10, no. 2 (1998): 591.

48 Boulby, 'The Islamic Challenge: Tunisia since Independence,' 591.

49 Boulby, 'The Islamic Challenge: Tunisia since Independence,' 591.

50 Boulby, 'The Islamic Challenge: Tunisia since Independence,' 591.

51 During the fight for independence, Bourguiba's PSD party used Islamic institutions and symbols creatively to attract a mass support base.

52 Habib Bourguiba was referred to as a child of enlightenment, educated in law and political science at the Sorbonne. Bourguiba, took his political inspiration from Rousseau, Lamartine and Hugo. 
relating to the role played by Islam. Following independence in 1956, the emerging Tunisian authorities implemented a series of legal reforms that formed Tunisia's legal system in its current form. Under Tunisia's first postindependent president, Habib Bourguiba, set in motion a series of changes relating to Islam, for example the codification of its family law and the abolishment of Shariah Courts, various tribunals and French courts..$^{53}$ The judiciary became unified and Tunisian law applied to all persons within the country. It could very well be argued that the existing French law acted as a basis for certain of the reforms, particularly, civil law. ${ }^{54}$ This is hardly surprising, as Bourguiba was a graduate of the Sorbonne University.

In creating a modern Tunisia, the Bourguiba led government introduced a notable policy the codification of its family law the Code of Personal Status (CPS) in 1956 - 1957. ${ }^{55}$ The codification of Tunisia's family law offended many orthodox Muslims as they viewed the CPS as a direct attack against Islam. ${ }^{56}$ The aim of the CPS was to improve the legal position of women by reforming Tunisia's existing family law (which was at that time not codified), which was in the hands of Muslim clerics under the French Protectorate. Polygamy was banned and the code required that a man could no longer obtain a divorce by merely renouncing his wife without the intervention of judicial authority of the state. ${ }^{57}$ Although some of the Muslim clerics immediately issued a fatwa

53 Proctor \& Moussa, 'The Tunisian Constituent Assembly's By-laws: A Brief Analysis.'

54 One of the central aims of Borguiba's modernity was the reforms relating to education. The educational reforms relating to the 'ulamā' (Muslim clerics) was profound. Unification of the education system meant the elimination of religious schools and Zaytouna scholars were deprived of their traditional role as teachers. The Zaytouna Mosque was integrated into the newly created Tunis University featuring a western-style curriculum. Religious education was reduced to only two hours per week. Although job opportunities were created for Zaytouna graduates as religious educators, the content as well as method of religious instructions were controlled by the state.

55 Mashour, 'Islamic Law and Gender Equality: Could There Be A Common Ground?: A Study of Divorce and Polygamy in Sharia Law and Gender Equality,' Human Rights Quarterly, vol. 27, no. 2 (2005): 566.

56 Boulby, 'The Islamic Challenge: Tunisia since Independence,' 591.

57 The Tunisian Code of Personal Status of 1956, Book 1, article 18. Marrying more than one woman shall incur punishment of one imprisonment and a affine of 240000 francs or either of these. In addition, arguing that polygyny that the Qur'anic verse requiring the equal treatment of wives was an impossible ideal. Furthermore, polygyny could be equated to slavery and should be prohibited as the practice was revealed in a special context at the time of revelation. 
(religious decree) putting forward their own legal position denouncing the CPS, several clerics not only approved the new policy but accepted positions as judges defending the CPS in the newly established secular courts. ${ }^{58}$ This was in effect a top-down policy by the government, when at a time the feminist movement was not as solidified as it is now in Tunisia. Furthermore, it could be argued that the introduction and codification of family law was to break the existing stranglehold that Muslim clerics and tribal leaders in the rural areas held onto, instead of the emancipation and improvement of the status of women in Tunisia.

\section{ISLAM, WOMEN AND BEN ALI}

From the mid-1940s to the 1970's as in many Muslim dominated societies, religion was controlled by the state. It is reported that only after this period that an Islamist ${ }^{59}$ movement revival becoming visible in direct response to the implementation of state policies, envisaging and overall programme and language of political control of issues such as religion, social, economic and cultural life of Muslim living in Muslim countries. ${ }^{60}$

In 1987, the then Prime Minister Ben Ali, ${ }^{61}$ declared a sitting president Bourguiba mentally and physically incompetent to hold the presidency and

58 Shults, 'Tunisia: Democracy and Islam in post-Arab Spring Politics,' http:// scholar.utc.edu/honors-thesis, accessed on 13 October 2018.

59 Simply explained, Islamism, or political Islam, accords Islam as a political movement encapsulating religious beliefs together with political ideologies. According to Rodger Hardy, political Islam is the notion that Islam is not only a religion and a way of life but an all-encompassing political and social ideology. Therefore, Islamist parties are normally characterised by a urge to afford Qur'anic principles into existing legislation, which not limited to radical and conservative Shariah. Islamism it is argued to have sprung its roots during the colonial period and conceptualised in Egypt during the British period of colonialism in a bid to unite Egyptians through the use of religion against the British. It sought to assimilate the seventh century period of Prophet Muhammad [Peace and Blessings Upon Him] in Medina. The Islamism movement objective was unite those Muslims who were oppressed during the colonial period by the colonial masters.

60 Proctor \& Moussa, 'The Tunisian Constituent Assembly's By-laws: A Brief Analysis.'

${ }^{61}$ Ben Ali ruled Tunisia for 23 years and ended with the "Jasmine Revolution". 
took over the office in a bloodless coup d'état. ${ }^{62}$ A notable feature of the Ben Ali presidency was characterised by repressive control and persecution of political opponents and various religious groupings. ${ }^{63}$ For example, Ennahda a middle-of the-road influential Islamist party which was formed in 1981 was banned because of its Islamic agenda and many took refuge abroad evading the Ben Ali presidency. ${ }^{64}$ From the above it may be argued that the restricting of political participation and freedom of expression was a mechanism that was employed by the then Ben Ali presidency to maintain power and quashing any political opposition. ${ }^{65}$ As far as Islam was concern, and in particular the CPS, minimal changes were introduced and these were by and large seen as insignificant from the perspectives of gender equality, however, these changes served as a further break from the traditional Shariah according to Charrad. ${ }^{66}$

During the Ben Ali term, women's trajectory relating to education and economic empowerment continued. In 1991, reforms to the educational system made attendance for both girls and boys from the ages of 16 years compulsory, result in a dramatic increase in the enrolment rates at secondary schools. ${ }^{67}$ Today, the enrolment figures at universities show more females than males, and women constitute 27.9 percent of the labour as at $2007 .{ }^{68}$ Sadly, inequity exists, particularly in rural settings, where women hardly own land and are overwhelmed by having to balance both domestic and farm activities. ${ }^{69}$ Furthermore, in the private sector, women are not often promoted to managerial positions, and in most instances earn less than men in the same position. ${ }^{70}$

62 Omri, 'The Status of Women under Tunisian Law,' Journal of Policy Studies, vol. 18 (2004): 147-161.

63 Proctor \& Moussa, 'The Tunisian Constituent Assembly's By-laws: A Brief Analysis.'

64 Arieff, 'Political Transition in Tunisia Congressional Research Service Report for Congress,' http://www.refwold.org, accessed on 14 October 2018.

65 Khalil, 'Tunisia's Women: Partners in Revolution,' Journal of North African Studies, vol. 19, no. 2 (2014): 192.

66 Charrad, 'Tunisia at the Forefront of the Arab World: Two Waves of Gender Legislation,' Washington and Lee Law Review, vol. 64, no. 4 (2007): 1527.

67 Salem, 'Tunisia.'

68 Salem, 'Tunisia.'

69 Salem, 'Tunisia.'

70 Salem, 'Tunisia.' 
According to Shults, these changes afforded Ben Ali the support of the West through its secular practices and demonstrating that the Islamist parties were towing the line in Tunisia. ${ }^{71}$ Some may argue that restricting political participation of parties and other measures that were put in place was decidedly undemocratic, would be correct. It is however, against this imperious regime of Ben Ali that created the space for protest of the Arab spring and the ensuing road to a more democratic and participatory environment for Tunisia. It could very well be argued that Tunisia under the Ben Ali regime saw the country lapse into state of authoritarianism. ${ }^{72}$ Islamic activists after the Arab-uprising initiated an organisation called the "Friends of the Al-Zaytuna Mosque" its aim was to re-establishing the closed institution. ${ }^{73}$ After the mobilisations of the masses, and petitions, the organisation obtained a court order giving the organisation the right to re-open the Al-Zaytuna mosque. ${ }^{74}$

\section{PART B - THE TUNISIAN CONSTITUTIONAL MAKING PROCESS - CONTEXT, PROCESS AND PARTICIPANTS}

The Fundamental Pact, ('ahd al-aman in Arabic) which was promulgated in Tunisia in 1857, was legally adopted as the country's constitution in 1861, at which point it became the first written constitution in the Arab World. Ebrahim Afsah argues that constitutional struggles in the Arab world are often explained by a lack of institutional tradition. Therefore, the long history of constitutionalism in Tunisia could help explain the relative success of the country's democratic transition, as compared with other Middle Eastern and North African countries that experienced protest to a larger or lesser degree.

The protest that Tunisia, experienced could be attributed to its authoritarian government. A notable feature of such governments is the lack of free and fair elections as well as the imposition of various restrictions imposed on the formation and well-being of political parties. ${ }^{75}$ Tunisia had few if any

\footnotetext{
$71 \quad$ Shults, 'Tunisia: Democracy and Islam in post-Arab Spring Politics.'

72 Majalla's Notes, 'Islamism in the Maghreb: Taming Islamists by Integrating Them Into the Political System,' http://facebook.com, accessed on 26 September 2018.

73 Croitoru, 'Controversy Surrounding the Al-Zaytuna in Tunis: The Ambivalent Revival of Islamic Traditions.'

74 Croitoru, 'Controversy Surrounding the Al-Zaytuna in Tunis: The Ambivalent Revival of Islamic Traditions.'

75 Dewey, Kaden, Marks, Matsushima \& Zhu, 'The Impact of Social Media on Social Unrest in the Arab Spring,' http://www.publicpolicystanford., accessed on 5 January 2019.
} 
institutional mechanisms designed to identify and to respond to the demands of protests. The lack of the appropriate feedback mechanisms that has the ability of advising the government and the seriousness of the discontent of the protesters render those governments incapable of identifying and taking appropriate action in a timely manner. ${ }^{76}$ In addition, such governments, may lack transparency and provide little respect for the rule of law and human rights principles. The atmosphere in Tunisia could characterised by detentions and arrest without due process, torture, trails without substantive procedures in place and disappearances. ${ }^{77}$ Under an authoritarian style government, instances of mass protests and political opposition could be curtailed or simply brushed aside. $^{78}$

The effect of the post-Jasmine revolution resulted in an almost vacuum at this stage of the process in Tunisia. With the Ben Ali presidency (including the ruling party to which he belonged) being forced out as well as dismembered, the formerly banned parties started a process of acknowledgment. ${ }^{79}$ From January 2011 Tunisia entered a transition period towards democracy. In contrast to independence which was largely a national movement, the Jasmine revolution in Tunisia was not led by a singular movement or party but rather ignited by Tunisians frustration and led mostly by the youth whose anger stemmed by a lack of opportunities and the absence of the most basic of fundamental human rights.

In an attempt to occupy the political vacuum, Ben Ali's Prime Minister Mohammad Ghanouchi, based on article 56 of the Tunisian constitution of 1959, declared himself as acting president. ${ }^{80}$ However, the application of article 56 was interpreted as the absence of the President is temporary, not

76 Dewey, Kaden, Marks, Matsushima \& Zhu, 'The Impact of Social Media on Social Unrest in the Arab Spring.'

77 Dewey, Kaden, Marks, Matsushima \& Zhu, 'The Impact of Social Media on Social Unrest in the Arab Spring.'

78 Dewey, Kaden, Marks, Matsushima \& Zhu, 'The Impact of Social Media on Social Unrest in the Arab Spring.'

79 The Ben Ali regime came to an end on the $14^{\text {th }}$ January 2011.

80 The Tunisian Constitution of 1959, article 56, Temporary Disability, which reads; (1) In the case of temporary disability, the President of the Republic may, by decree, delegate his powers to the Prime Minister with the exclusion of the power of dissolution, (2) During the temporary disability of the President of the Republic, the Government, even if it is the object of motion of censure, remains in place until the end of this disability, (3) The President of the Republic shall inform the President of the President of the Chamber of Deputies and the President of the Chamber of Advisors regarding such temporary delegation of his powers. 
permanent. However, this issue was resolved by the constitutional council, being the highest arbiter relating to constitutional issues then. The constitutional council ${ }^{81}$ pronounced that due to the absence of the president the situation requires intervention of article 57, therefore, the head of the lower chamber of parliament, not the prime minister, should serve as interim president. ${ }^{82}$

The interim government set about handling the new Tunisia by installing the High Commission for the Realization of Revolutionary Goals, Political Reform, and Democratic Transition. ${ }^{83}$ Inference may be drawn from the title that the objectives were to accommodate the demands of the current sociopolitical paradigms. ${ }^{84}$ Due to the deaths of protesters, Mebazza, set in motion a road map as well as the date for the election of a National Constituent Assembly (NCA) that would be tasked with the drafting of Tunisia' new constitution as well as putting aside the 45-60 day constitutional limit ${ }^{85}$ relating to his term as interim president. $^{86}$ The interim president further proclaimed that 1959 constitution no longer meets the needs of the people after the uprising,${ }^{87}$ clearing the road for the Decree-Law No. 2011-14 to put aside the 1959 constitution permanently. ${ }^{88}$ The High Commission, surprisingly, was initially instituted to act in an advisory capacity however the High Commission assume more power and unofficially acted as an unelected parliament. ${ }^{89}$

81 The Tunisian Constitution of 1959, article 75.

82 The Tunisian Constitution of 1959, article 57. Accordingly, Fouad Mebazza, was installed as interim president of the Tunisia.

83 Nouira, 'Obstacles on the Path of Tunisia's Democratic Transformation,' Carnegie Endowment for International Peace, http://carnegieendowment.org, accessed on 12 October 2018.

84 El-Sayed, 'Post-Revolution Constitutionalism: the Impact of Drafting Process on the Constitutional Documents in Tunisia and Egypt,' Electronic Journal of Islamic and Middle Eastern Law, vol. 2 (2014): 39-62. The commissions initial role was establishing a platform for the representation on the various role players and the Tunisia community.

85 The Tunisian Constitution of 1959, article 57.

86 BBC News, 'The Tunisian President Fouad Mebazza Calls Election,' http://www. bbc.co.uk/news/world-middle-east, accessed on 10 October 2018.

87 BBC News, 'The Tunisian President Fouad Mebazza Calls Election.'

88 El-Sayed, 'Post-Revolution Constitutionalism: the Impact of Drafting Process on the Constitutional Documents in Tunisia and Egypt,' 39-62.

89 El-Sayed, 'Post-Revolution Constitutionalism: the Impact of Drafting Process on the Constitutional Documents in Tunisia and Egypt,' 39-62. 
The NCA was elected in October 2010 with a nearly 70 percent turnout. ${ }^{90}$ Ennahda, seen as a moderate Islamic party, attained numerous votes (41.7 percent) and seats ( 89 of 217), this however did not represent a majority. ${ }^{91} \mathrm{~A}$ coalition government ${ }^{92}$ was formed, comprising the following parties, Ennahda (the main winner of the elections), the Centre Nationalist party (CPR Congrés pour la République) and the socialist party Ettakatol (Forum démocrtique pour le travail et les libertés), at the helm was Mustapha Ben Jafaar, chairman of the NCA..$^{93}$

To include strong women participation, the NCA, imposed that every other candidate on the relevant electoral form had to be a woman. ${ }^{94}$ Surprisingly Ennahda, showed extreme willingness to gender-parity, trumping other secular parties that had been allotted seats in the NCA. Although it could be argued that certain structures were in place to ensure the participation of women, even so, the commitment by the Ennahda party to gender-parity demonstrated a willingness to compromise.

The NCA basic goal was tasked with the drafting of a new constitution for Tunisia in addition its powers were expansive in that it could decide its own

90 Proctor \& Moussa, 'The Tunisian Constituent Assembly's By-laws: A Brief Analysis.'

91 Proctor \& Moussa, 'The Tunisian Constituent Assembly’s By-laws: A Brief Analysis.'

92 The elections to the NCA were based on a system of pure proportional representation thus this system worked against majoritarianism and in a favour of a coalition. The result was an NCA that included 19 different parties and 8 independent representatives. Modern day scholars of electoral theory agree that had a 'first-past-the-post' system had been engaged, the Islamist Ennahda party would have won up to 90 percent of the seats - rather than the 41 percent they finally achieved. As it was, the Ennahda party was to certain degree forced into forming a coalition with various secular parties.

93 Proctor \& Moussa, 'The Tunisian Constituent Assembly's By-laws: A Brief Analysis.'

94 Böckenförde, 'The Dynamics of Comprehensive Constitution-building: Religion and the Concept of Twin Tolerations in Tunisia,' The Tunisian Constitutional Process: Main Actors and Key Issues, ed. Mathieu Rousselin \& Christopher Smith (Duisberg: Käte Hamburger Kolleg / Centre for Global Cooperation Research, 2015), 24-35. 
by-laws as well governing the country through the transitional period. ${ }^{95}$ The NCA was compartmentalized into six constituent commissions, each have a role in drafting a specific part of the new constitution. The first five constituent commissions were tasked with the preamble and fundamental principles, local government entities, rights and freedoms, executive and legislative powers including their relations and justice and constitutional bodies. ${ }^{96}$ The sixth commission essentially a drafting and synthesis was tasked with the consolidation of efforts of the other commissions into a harmonised document. ${ }^{97}$

In 2012 the drafting of Tunisia's new constitution in all earnest began, following the conclusion of all internal structures of the NCA. As expected, with any new process relating to a constitution heated debates ensured on issues such as, state identity, the role of religion in state and society, the political system, the place of human rights and the role of women. ${ }^{98}$ As would be expected, all participants had divergent views on the above-mentioned issues, however, the members of the NCA managed to reach an agreement on a variety of issues, such as, article 1 of the old constitution, which states the identity of the state and postulates Islam as the religion of the state as well as identifying Shariah as a main source of law, as formerly demanded by a few Islamist participants. ${ }^{99}$

In August 2012, the various constitutional commissions submitted each their first draft to the drafting committee, which highlighted issues such as repetitions, gaps, vague phrasing, however, no substantive modifications to

95 Given the scope of powers awarded to the NCA, this body became extremely powerful lacking clear limitations and the discharge of such powers. It became apparent, that the make-up of the NCA developed two foreseeable mistakes firstly drafting a constitution based on political authority and not consensualism, secondly, the absence of any criteria relating to accountability. This in contrast that the political parties agreed that the mandate of the NCA should not exceed a period of one year, however, the agreement was non-binding and many assumed that it will not be honoured.

96 Shaqoura \& Kristiansen, 'Islam and Human Rights: The Constitutional Debate in Tunisia.'

97 Shaqoura \& Kristiansen, 'Islam and Human Rights: The Constitutional Debate in Tunisia.'

98 Shaqoura \& Kristiansen, 'Islam and Human Rights: The Constitutional Debate in Tunisia.'

99 Shaqoura \& Kristiansen, 'Islam and Human Rights: The Constitutional Debate in Tunisia.' 
the content of the articles took place. ${ }^{100}$ Between then and the final adoption of the text in January 2014, a further three variants were published for comment and redesign. The overall objective was to formalise the new constitution with in a period of one year, unfortunately the process continued well beyond the proposed deadline of October 2012. ${ }^{101}$ The constitutional process was further delayed with the assassination of Chokri Belaid, a leading politician in February 2013, as well as Mohamed Brahmi, a less influential liberal. ${ }^{102}$ The second assassination led to sixty NCA members to resign which caused and uneasiness in NCA. ${ }^{103}$ In 2013, two years after the election of the NCA, a stimulus was ignited to unite the various factions and to bring end to the stalemate that came about with the second assassination. Throughout the constitutional process, civil society played a dominant role in monitoring the process and the voicing of opinions. The observatory referred to as Marsad concentrated on the monitoring of the debates within the NCA, civil society and was vocal about the rights of women whereas the broader public followed these debates on various social platforms. ${ }^{104}$

Due the existing stalemate, prompted Tunisia's oldest civil participants to amalgamate in an effort to forward the constitutional process which ultimately was the finalisation thereof. ${ }^{105}$ They would become known as 'the quartet', the General Tunisian Union of Work (UGTT), the Tunisian Union of Industry, the Commerce and Crafts (UTICA), the Tunisian League of Human Rights (LTDH) and the National Organisation of Tunisian Lawyers (ONAT). ${ }^{106}$ The

100 The Carter Center, 'The Carter Congratulates Tunisia's National Constituent Assembly on Final Draft of Constitution and Urges Safeguards for Human Rights,' http://cartercenter.org, accessed on 2 October 2018.

101 Shaqoura \& Kristiansen, 'Islam and Human Rights: The Constitutional Debate in Tunisia.'

102 Shults, 'Tunisia: Democracy and Islam in post-Arab Spring Politics.' An extremist conservative group, Ansar al-Sharia was blamed for both deaths.

103 El-Sayed, 'Post-Revolution Constitutionalism: the Impact of Drafting Process on the Constitutional Documents in Tunisia and Egypt,' 39-62.

104 Marsad, http://www.marsad.tn/fr/, accessed on 3 October 2018.

105 Schäfer, 'The Tunisian Transition: Torn Between Democratic Consolidation and Neo-Conservatism in an Insecure Regional Context,' European Institute of the Mediterranean, http://www.die-gdi.ide, accessed on 19 October 2018. On 9 October 2015, the Nobel Prize Committee announced the Tunisian Quartet as the winner of the Nobel Peace Prize.

106 All four organisations existed under the Ben Ali's presidency and in particular the UGTT and UICA were accustomed at meeting at the negotiating table and partaking in the social discourse before the Arab uprising. 
quartet operated outside the realm of the NCA even when inside the NCA it did not seem that consensus would be reached and that the finalisation of the constitution would not be attained. ${ }^{107}$ At first, Ennahda party leadership refused to acknowledge the legitimacy of the quartet, arguing that Ennahda and its political allies were victorious in the elections, whereas the quartet was seen as a group of self-appointed civil society leaders. ${ }^{108}$ It could be argued that Ennahda and others viewed the quartet without have legitimacy, as the quartet did not participate in the elections. However, as the protest swelled in Tunisia coupled with the removal of Egypt's Morsi as well as observers around the world, Ennadha and other political allies agreed to put their differences aside and to put on track the constitutional process. ${ }^{109}$

So far, we have looked at the internal participants of the constitutional process in Tunisia, in addition there were also other international participants that played a role in this process. From an international perspective, the participants included various United Nations (UN) agencies of the UN Country Team (UNCT), the European Union (EU) as well as a number of international NGOs monitored and supported the constitutional process wherever possible. ${ }^{110}$ The UN support was conducted through the UNCT and its agencies comprising of the Office of High Commissioner for Human Rights (OHCHR), under the auspices of the UN Development Programme (UNDP). These international participants concluded a co-operation agreement with the NCA to support the constitutional building process in Tunisia. The focus of the agreement between the UN and Tunisia was to lay a legitimate foundation for the creation of a new social contract not only from an internal perspective but also from an international perspective as the entire international community was focussing on the constitutional-making process. The result of the various participants would have the effect of the process being observed as being transparent

107 Besides the UGTT, numerous human rights, lawyers, women and other civil society organisations were and still committed in pushing forward the transition process in their respective fields. Under the previous regime, the possibilities for civil society activities were limited, and often restricted by censorship and/or repression. After the Arab uprising, a lacuna was created for the manoeuvrability which resulted in the explosions of participants in the constitutional process.

108 Tamaru, Holt-Ivry \& O'Reilly, 'Beyond Revolution: How Women Influenced Constitution Making in Tunisia,' http:// www.inclusivesecurity.org, accessed on 19 October 2018.

109 Tamaru, Holt-Ivry \& O’Reilly, 'Beyond Revolution: How Women Influenced Constitution Making in Tunisia.'

110 Shaqoura \& Kristiansen, 'Islam and Human Rights: The Constitutional Debate in Tunisia.' 
and inclusive constitutional building process in Tunisia. Some members of 'the quartet' were accused of as being subservient to their economic interest rather than to its core objectives. ${ }^{111}$ It is for that reason not exclusively that the Ennahda party leadership and other political parties refused to acknowledge the legitimacy of the quartet.

The events that have triggered the departure of former president Ben Ali, has been closely followed by the OHCHR. ${ }^{112}$ Navi Pillay, UN High Commissioner for Human Rights, announced that a team of experience officers are to be deployed to Tunisia, to assist the country in achieving its human rights aspirations, and those who has sacrificed will not have been in vain. ${ }^{113}$ The roles played by the $\mathrm{OHCHR}{ }^{114}$ and the UNCT was to lobby for the inclusion of advocacy activities relating to human rights standards and principles to accompany the draft text of the constitution leading up to the final draft. To attain this goal, a joint brief by the OHCHR and the UNCT prescribing the application of international human rights standards affording human rights and the rule of law to all members of the NCA in 2012. ${ }^{115}$ The OHCHR commented

111 De Silva de Alwis, Mnasri \& Ward, 'Women and the Making of the Tunisian Constitution,' http://acholarship.law.upenn.edu, accessed on 19 October 2017.

112 Office of the United Nations High Commissioner for Human Rights (OHCHR), 'Report of the OHCHR Assessment Mission to Tunisia 26 January 2011 to 2 February 2011,' http://www.ohchr.org/encountries/menaregions, accessed on 19 October 2018.

113 Office of the United Nations High Commissioner for Human Rights (OHCHR), 'Report of the OHCHR Assessment Mission to Tunisia 26 January 2011 to 2 February 2011.'

114 The purpose of the OHCHR was to, explore possibilities for the advancement of human rights in Tunisia in light of the extraordinary turn of events, gain a firsthand understanding of human rights challenges and to discuss with a broad range of actors, including the Transitional Government, civil society groups and the UN Country Team, how OHCRH can assist the people of Tunisia in strengthening respect for all human rights in the country, and report to the $\mathrm{HC}$ on its observation and recommendations. See Office of the United Nations High Commissioner for Human Rights (OHCHR), 'Report of the OHCHR Assessment Mission to Tunisia 26 January 2011 to 2 February 2011.'

115 Shaqoura \& Kristiansen, 'Islam and Human Rights: The Constitutional Debate in Tunisia.' 
on certain provisions of preliminary drafts and offered recommendations to NCA to integrate international standards in its process. ${ }^{116}$

The role played by women in the constitutional building process cannot be underestimated. The Tunisian Association of Democratic Women (ATFD) and The Association of Tunisian Women for Research on Development (AFTURD), both established in 1989, during the Ben Ali regime became powerhouses of activism when Ben Ali was ousted. ${ }^{117}$ The constitutional process created a public space for women's movements, as a result women were well represented in the NCA decision-making committees, sadly, only a few women were appointed to significant positions of leadership. ${ }^{118}$ Although, women only occupied a few positions of authority, many were appointed as deputies of the various constituent committees relating to drafting process under specific constitutional themes, of interest, the only committee headed by a woman was the committee on human rights and liberties, which dealt with issues relating to women's rights. ${ }^{119}$ Women's organisations also acted as effective poll-watchers, constantly monitoring the NCA and highlighting any anomalies in the drafting process making women and women's organisations more visible.

A case in point is South Africa, the participation of women and their organizations played a crucial role for the amalgamation of women's

116 Geneva International Centre for Justice, 'Tunisia's UPR-2017 (conferencesmeetings/upr-sessions/1070-tunisia-s-upr-2017), ' http://www.gicj.org/oppositions -opinions, accessed on 19 October 2018. For example, equality and nondiscrimination: the OHCHR recommended criminalizing racism, in line with international commitments. The country team reported that article 250 of the Criminal Code criminalized sexual relations between the persons of the same sex and expressed concern for cases of discrimination against the members of the Amazigh minority, human rights and counter-terrorism: the 2015 mission report, the Special Rapporteur on torture stated that they heard that tens or even hundreds of individuals had been subject to ill-treatment or even torture in the context of counter-terrorism operations. Right to life, liberty and security of the person: the Committee against torture was concerned about reports of incommunicado detention before arrest had been officially registered in cases relating counterterrorism activities and in which claims of torture had been made.

117 De Silva de Alwis, Mnasri \& Ward, 'Women and the Making of the Tunisian Constitution.'

118 De Silva de Alwis, Mnasri \& Ward, 'Women and the Making of the Tunisian Constitution.'

119 De Silva de Alwis, Mnasri \& Ward, 'Women and the Making of the Tunisian Constitution.' 
movements where previously they were either non-existent or played a limited role in civil society. In 1992, the South African Women's National Coalition embarked upon stimulating public awareness and creating a platform for the discussions surrounding the rights of women. ${ }^{120}$ During the transition period in South Africa, this organization highlighted several areas of concern for the new South Africa, for example, inclusivity in the decision making process, awareness and the promotion of women's rights, gender equality and the uniting of women. ${ }^{121}$

Around 1994, the South African Constituent Assembly (SACA) in the early stages of the drafting process of a new constitution started out to include a broad base participatory platform which was grounded in three major points, inclusivity, accessibility and transparency. ${ }^{122}$ These included, an educational push using billboards, newspapers, radio, television and hotline to inform and educate the public about constitutional issues and the right of the public to participate in the constitutional building process. ${ }^{123}$ Of note, more than one thousand educational workshops were organised within a period of one year. ${ }^{124}$ This process allowed members of the SACA, to meet members of the community and to address the concerns of South African people. Public consultations were held relating to specific issues, such the Bill of Rights, the judiciary as well as the administration of the way forward for South Africa. ${ }^{125}$ The SACA held a two year deliberation which was transparent and included the input of the all South Africans, in part due to the push by women and the South African Women's National Coalition Movement.

120 De Silva de Alwis, Mnasri \& Ward, 'Women and the Making of the Tunisian Constitution.'

121 Murphy, 'Constitutional Rights Discourse: Canadian and South African Feminist Engagements,' in Women Making Constitutions: New Politics and Comparative Perspectives, ed. Alexandra D \& Hart V (London: Palgrave Macmillan, 2003), 21-23.

122 Albertyn, 'Towards Substantive Representation: Women and Politics in South Africa,' in Women Making Constitutions: New Politics and Comparative Perspectives, ed. Alexandra D \& Hart V (London: Palgrave Macmillan, 2003), 99-117.

123 Brandt, 'Constitutional-Making and Reforms: Options for the Process,' http:// constitutionalmakingforpeace.org, accessed on 19 October 2018.

124 De Silva de Alwis, Mnasri \& Ward, 'Women and the Making of the Tunisian Constitution.'

125 De Silva de Alwis, Mnasri \& Ward, 'Women and the Making of the Tunisian Constitution.' 


\section{THE CONSTITUTION AND ISLAM}

From the beginning of Tunisia's constitutional transition, the identity of the state would be a contentious issue. The dilemma concerned the cohesion of the various elements that carved out the Tunisian state and how that identity could find an alignment with the rights and freedoms that would eventually form part of the constitution. The right to freedom of religion or belief is one of many foundational principles of international law (and in some constitutions globally) and it would be essential that it is protected and explicit in constitutional drafts and transition. ${ }^{126}$ This right is codified by article 18 of the Universal Declaration of Human Rights (UDHR) ${ }^{127}$ as well as article 18 of the International Covenant on Civil and Political Rights (ICCPR), ${ }^{128}$ is a commodious right encompassing a large number of issues.

As early as the 1970's, the Ennahda party has been an opposition tool to post-independence Tunisia one the most contentious issue was the role of religion in the state and wider society. ${ }^{129}$ Party members had openly disagreed which they viewed as an anti-Islamic government and attacking its secularist policies. Of note, during the Ben Ali presidency the Ennahda party was the political tension that led to trails, imprisonment and ultimately the exile of Ennahda members. ${ }^{130}$ Post Jasmine revolution, the issue of religion within the public sphere become more prominent resulting in victory of Ennahda in the elections, and thrusting forward the role of religion in the constitutional building process.

126 The Carter Center, 'The Carter Congratulates Tunisia's National Constituent Assembly on Final Draft of Constitution and Urges Safeguards for Human Rights.'

127 Universal Declaration of Human Rights, GA Res 217A (III), GOAR $3^{\text {rd }}$ Session, Resolutions, (Part 1) UN Doc A/810, adopted 10 December 1948.

128 International Covenant on Civil and Political Rights, GA Res 2200 (XXI), UN GAOR $21^{\text {st }}$ Session, Supp No 16, UN Doc A/6316 (1996) UNTS 171, adopted 16 December 1966.

129 Karray, 'The National Constituent Assembly, Historical Lessons and Contemporary Stakes,' Right to Nonviolence Tunisia Constitutional E-Forum, http://www. rightononviolence.org/mecf/mr-bassem-karray, accessed on 19 October 2018.

130 The Ben Ali presidency set out to prevent religious influences on Tunisian society by prohibiting the establishment of religious-fused parties by observing and monitoring Islamist militants. 
The Tunisian constitution of $1959,{ }^{131}$ makes mention of Islam, though in a dampened context, in a way that it acknowledges Islam as the religion of Tunisia as contained in article 1, and was not expressly stated as primary or formal source of law. ${ }^{132}$ Reference to Islam is also mentioned in the preamble and article 38 therefore inferences may be drawn from the 1959 constitution that Islam remained to a certain degree neutral on the issue of religion. ${ }^{133}$ According to Charfi, a legal scholar, article 1 of the 1959 constitution, indicated that the Tunisian majority were Muslims and as such indicated it to be so and that the state did not ignore the sociological realities or certain peculiarities relating to Islam. ${ }^{134}$

The question of how to interpret article 1 of the old constitution into the new constitution was the subject of much deliberation in the NCA, the media, and civil society in Tunisia. The preamble of the first draft submitted in August 2012, referred to the aims of Islam as a source of inspiration and stood firm on the Islamic identity of the country. ${ }^{135}$ The preamble of first draft of 2012 therefore acknowledges the state as protector and guarantor of religion as well as the freedoms of conscience and exercise of faith. In addition, the preamble also acknowledges the sacredness and neutrality of sites of worship against partisan propaganda. Furthermore, the provision that 'Islam is the religion of the state' imposing that this provision is exempted from all possible review. ${ }^{136}$

131 The Constitution of Tunisia - "In the Name of the people, We, Habib Bourguiba, President of the Republic of Tunisia, Considering the Decree of December 29, 1955 (14 Djoumada 1 1375) establishing the Constituent National Assembly, Considering the decision of the Constituent National Assembly of July 25, 1957 (26 Dhoul-hidja 1376), and With the approval of the Constituent National Assembly, Promulgate the following Constitution of the Republic of Tunisia", the content which reads as follows.

132 The Republic of Tunisia, The Constitution of Tunisia of 1959, article 1 which reads: "Tunisia is a free, independent and sovereign state. Its religion is Islam. Its language is Arabic and its type of government is the Republic."

133 Chapter III, The Executive Power, article 38 which reads: "The President of the Republic is the Head of State. His religion shall be Islam."

134 Charfi, Islam and Liberty: The Historical Misunderstanding (London: Zed Books, 2005), 12-13.

135 Shaqoura \& Kristiansen, 'Islam and Human Rights: The Constitutional Debate in Tunisia.' Thirty articles of the first draft were submitted with alternative language, ranging from two to five options for a single article.

136 Article 145 of the 2014 constitution posits that the preamble is an integral part of the constitution, in addition, article 146, reads that the dispositions of the constitution are part of and explained as a harmonious whole. 
The second draft was submitted in December of 2012, declares that the constitution will be founded on the fundamental principles (thawabit) ${ }^{137}$ of Islam and that its aims are openness and moderation founded on the heritage of the Tunisian people as well as illuminating the Islamic and Arab identity of the country. However this is softened by making reference to the universal values as well as to the historical and cultural heritage of the Tunisian people. Article 4 , of the second draft also recognises Islam as religion of country just as the first draft. ${ }^{138}$ In addition, article 4, also recognises the state as the guarantor of religion, freedom of belief, the practice of religion including the protector of the sacred and the guarantor relating to neutrality of worship sites in relation to partisan propaganda. ${ }^{139}$

The third draft was submitted in April 2013, included article 1 and acknowledges the role of Islam as Tunisia's main religion. As in the second draft of December 12, the third draft of April 2013, it stresses that the constitution will be founded on 'fundamental principles (thawabit) found in Islam' expressing that the constitution will characterised by openness and moderation. In addition, it refers to the universal human rights principles as noble human values with the only caveat, that these human rights principles are consistent with the Tunisian people culture specificities. It seems that the April 2013 draft edges further that its predecessors insisting on cultural specificity. The constitutional designers of this draft argue that inspiration for the above was founded by Tunisia's cultural heritage accumulated throughout history, the enlightened reformist movement based on elements of their ArabMuslim identity, the universal achievements of human civilisation and the their commitment to the national achievements of Tunisia as a whole. ${ }^{140} \mathrm{Of}$ note, these provisions which are to founded in the preamble amongst human rights activists, argue that these provisions found in the preamble could have negative connotations for the universality of human rights.

137 Etymologically, in Arabic the word thawabit refers more to 'constant principles' and does not share the same root with the word 'fundamentalist' (ussouliy derived from ussouls meaning fundament). The translation may therefore be misleading as it may suggest a more direct link between the wording used to translate thawabit and 'fundamentalism' as understood in its most current meaning. According to Shaqoura and Kristiansen, such a link is not obvious in Arabic.

138 Article 4, of the second draft of the Tunisian constitution of 2012 (draft).

139 Article 4, of the second draft of the Tunisian constitution of 2012 (draft).

140 Shaqoura \& Kristiansen, 'Islam and Human Rights: The Constitutional Debate in Tunisia.' 
The fourth draft was submitted in June 2013. In this instance the preamble aligns itself with the Arab-Islamic identity of Tunisia. In this draft the designers demonstrated that they are informed by "the teachings/doctrines of Islam displaying openness and moderation, human values, the universality of human rights. ${ }^{141}$ In addition, also acknowledging the Tunisian peoples national achievements, this too forms part of the preamble. ${ }^{142}$ Again, article 1 is maintained as Islam is recognised as the main religion of Tunisia.

The committee on consensus established in June 2013, reached a preliminary agreement as well as allowing further amendments which were proposed. The issue again centred, around Islam and its place in the preamble. According to Shaqoura and Kristiansen these included amendments to the preamble which refers to a process being based 'on the teachings of Islam' which were replaced by a tempered provision underlying 'the attachment of our people to the Doctrine of Islam". ${ }^{143}$ It was also argued the retraction of article 141 which referred to Islam as the religion of the state. ${ }^{144}$ Although, article 141, highlights several provisions that could not be amended, this was to be reformatted by two similar provisions, for example, article 1 'Tunisia is a free, independent and sovereign state, Islam is the religion, Arabic is the language and it is a republic', and Tunisia is a civil state based on citizenship and ruled by the will of the people as well as adherence to the rule of law, which was place outside the realm of amendments. These are as a result of the evolution of human rights which in part was fused by the advocacy of human rights organisations which in turn had the impact of solidifying of certain freedoms and liberties in the final draft. Disagreements over the June 2013 draft led to the creation of a Committee of Consensus (CC). ${ }^{145}$ The Committee of Consensus was responsible for the identification of contentious issues, collection and registration of views relating to contentious issues and to lead negotiations to resolving contentious issues. In addition, the Committee of Consensus and its panel assisting it

141 The preamble to the Tunisian constitution of 2013 (draft).

142 The preamble to the Tunisian constitution of 2013 (draft).

143 Shaqoura \& Kristiansen, 'Islam and Human Rights: The Constitutional Debate in Tunisia.'

144 Article 141 states, that the following provisions may not be subject to constitutional amendment: Islam as the religion of the State, Arabic as the official language of the State, the republican system of government, the civil character of the State, the human rights and freedoms guaranteed in the Constitution and the number of time extending the presidential mandate.

145 Abdesselem, 'The Making of A Constitution: A Look back at Tunisia's Thorny Consensus-Building Process,' http://www.constitutionnet.org, accessed on 26 October 2018. 
with various secularist opinions could be seen as in solidifying these norms. ${ }^{146}$ The fear or call by certain participants in the drafting process to add Islam as a formal source did not materialised, especially the early calls made by Ennahda. ${ }^{147}$ Although withdrawing its early comments relating to Islam as a source of any type of legislation/law, the reason could very well be that the characteristics of Tunisia was that it was a relatively secularised society where religious obligations are increasingly opined as a personal issue rather than a community or perhaps a clan prerogative. ${ }^{148}$

\section{WOMEN'S RIGHTS AND STATUS}

The status of women in Tunisia since the middle of the 1900's, have enjoyed an elevated status, albeit, from a family law perspective. Therefore, one would to a certain degree be correct in assuming that the issue of women would not arise within the constitutional building process. ${ }^{149}$ Of note, the CPS was registered in August 1956, only five months after independence and was applied in January of $1957 .{ }^{150}$ The Constituent Assembly (CA) which also acted as a legislative body (which convened in April 1956), surprisingly the text of the CPS was not

146 Abdesselem, 'The Making of A Constitution: A Look back at Tunisia's Thorny Consensus-Building Process.'

147 The Role of Islamic Law in Tunisia's Constitution and Legislation, http://www.loc. gov/law/help/tunisia.php, accessed on 9 October 2018. Some Ennahda members proposed a provision designating Shariah a source of legislation. Secularists and others opposed this as improperly Islamizing the legal regime. After significant discussions within the party and with others about the provisions reality, Ennahda announced it would not seek a Shariah reference.

148 Added to this as a framework that was characterised by a balance of power that did not enable the Islamist to impose their will; while they had a relative majority in the NCA, the government consisted of a coalition of parties, and a strong media and economic powers were placed outside the control of the holders of political might. This framework had to be taken into account during the constitutional phase and to the conclusion of the next elections, and could have had the impetus that allowed Ennahda to be more willing and creating a constitution would be consensual.

149 Tamaru, Holt-Ivry \& O’Reilly, 'Beyond Revolution: How Women Influenced Constitution Making in Tunisia.'

150 Zeghal, 'The Implicit Sharia: Established Religion and Varieties of Secularism in Tunisia,' in Varieties of Religious Establishment, ed. Winnifred Fallers Sullivan \& Lori G. Beaman (London: Ashgate, 2013), 107-130. 
debated or presented to the vote of the members of the constituent assembly. ${ }^{151}$ Surprisingly, the CPS promulgated by Bourguiba and his closest aides was removed from the deliberative sphere of the constituent assembly. ${ }^{152}$

The CPS underwent several amendments and created conditions that would have permitted women to fulfil their role in society in many aspects. These rights included the prohibition of polygyny and repudiation the legal right for women to ask for divorce, the establishment of a minimum age for marriage, the required consent of both parties to marriage have all furthered and strengthened the freedom and social status of women in Tunisia (there were areas where the CPS did fall short). ${ }^{153}$ However, the status of women in Tunisia did not escape the contentious arena from the constitutional building process. Women's organisations as well as human rights activist postulated concerns about the possibility of certain gains women acquired may be eroded as a consequence of the rise of Islamism in general as well as the dominant role of Ennahda in the NCA.

Of note is article 28 of the August 2012 draft which refers to role of men and women as being complementarity to each other. The drafting of this provision by the constitutional sub-committee approved the wording by a vote of 12 to 8 , "The State guarantees the protection of women's rights and support of its [their] achievements as a real partner of man in building a nation. Their roles within the family are complementary". ${ }^{154}$ For liberal women, the complementarity provision concretised the threat of Ennahda, for all its affirmations, sought to roll back women's hard fought achievements and to dominant the Tunisian society. International observers of the constitutional building process, such as Human Rights Watch, the Carter Center, and the Special Rapportuers and working groups from the UN Human Rights Council came out in opposition of article 28. ${ }^{155}$ These organisations postulated that the complementarity provision is an ambiguous concept, formatted on women's relationship to men rather than their universal human rights, and thus an inferior standard than full

151 Zeghal, 'The Implicit Sharia: Established Religion and Varieties of Secularism in Tunisia,' 107-130.

152 Zeghal, 'The Implicit Sharia: Established Religion and Varieties of Secularism in Tunisia,' 107-130.

153 Salem, 'Tunisia.'

154 Feuer, 'Islam and Democracy in Practice: Tunisia's Ennahda Nine Months,' http:// brandeis.edu, accessed on 20 October 2018.

155 Tamaru, Holt-Ivry \& O’Reilly, 'Beyond Revolution: How Women Influenced Constitution Making in Tunisia.' 
gender equality. ${ }^{156}$ The sustained pressure from all quarters on the NCA, article 20 of the June 2013 draft recognised the equality of men and women in rights and duties, equality before the law without discrimination, however, mainly in the qualities as citizens of society. ${ }^{157}$ Article 20 of the June 2013 draft, subsequently was adopted in the 2014 constitution as article $21 .{ }^{158}$ Article 46 of final draft provides "The state commits to protect women's accrued rights and work to strengthen and develop those rights, The state guarantees the equality of opportunities between women and men to have access to all levels of responsibility in all domains, The state works to attain parity between women and men in elected Assemblies, The state shall take all necessary measures in order to eradicate violence against women". ${ }^{159}$

\section{BLASPHEMYAND ITS RELATION TO THE FREEDOM OF RELIGION, EXPRESSION AND CONSCIENCE}

The affirmation of Islam as the religion of Tunisia on the one side, while on the other side the constitution which affirmed the state as the protector and guarantor of freedoms of conscience and exercise of faith, including the sacred and neutrality of sites of worship against any partisan propaganda, sparked debates concerning the potential tension of these provisions. The reason for debating this potential mix was that a series of events relating to freedom of expression in which various artworks viewed by Islamists as blasphemous and certain sites of worship were attacked. ${ }^{160}$

Activists argued that the hypocrisy of the state to act as guarantor of the freedom of conscious could create a limitation of the freedom of expression as well as potential cloak for unwanted state interference relating to the freedom of conscious and creation. ${ }^{161}$

156 Tamaru, Holt-Ivry \& O'Reilly, 'Beyond Revolution: How Women Influenced Constitution Making in Tunisia.'

157 Shaqoura \& Kristiansen, 'Islam and Human Rights: The Constitutional Debate in Tunisia.'

158 The Tunisian Constitution of 2014, article 21.

159 Tamaru, Holt-Ivry \& O'Reilly, 'Beyond Revolution: How Women Influenced Constitution Making in Tunisia.'

160 Certain artistic expressions and sites of worship had been explicitly threatened as well as the destruction of those places of worship.

161 Shaqoura \& Kristiansen, 'Islam and Human Rights: The Constitutional Debate in Tunisia.' 
The debate relating to place a ban on blasphemy, in which Ennahda members proposed initially, proposing a criminal prohibition applying to other Abrahamic faiths. ${ }^{162}$ After deliberations with others, Ennahda members withdrew the stipulation that blasphemy be criminalized, although provisions protecting religion remained in earlier drafts. ${ }^{163}$ The exposure of this debate stimulated changes to article 6 which now provides that the 'State is the guardian of religion', protects the 'sacred' and prohibits 'any offences thereto' and as prohibiting takfir (incitement to hatred). ${ }^{164}$ Civil society organisations critique these provisions as being sketchy and open to abuse as putting a noose around the neck of freedom of speech and religion as well as blasphemy. ${ }^{165}$ After repeated debates whether or not to constitutionally prohibit blasphemy, the NCA adopted a provision in the final constitution prohibiting 'any harm to the sacred, campaigns of accusing those of apostasy, incitement to hatred or violence'. ${ }^{166}$ In addition, the final text makes reference to insult, abuse of vilification, denial, accusation and defamation as well as guaranteeing the neutrality of mosques and sites of worship against any partisan instrumentalism and puts forward attempts to broadcasts the values of moderation and tolerance. ${ }^{167}$

To correct what may be perceived as an off-centre view of the European system of dealing with religion, democracy, as well as human rights, it would be prudent to gain insight of the following practices globally. ${ }^{168}$ The following examples may well provide that the European countries have perhaps fallen short of the standard that Tunisia achieved. Surprisingly, some of these provisions have received strong critique within the Tunisian constitutional context, whereas some of these are still very much alive on the European continent. The following examples are not set forward to concertize a strong

162 Aswad, 'The Role of Religion in Constitutions Emerging from Arab Spring Revolutions,' Georgetown Journal of International Affairs, vol. 16, no. 1 (2015): 159-169.

163 Aswad, 'The Role of Religion in Constitutions Emerging from Arab Spring Revolutions,' 159-169.

164 Aswad, 'The Role of Religion in Constitutions Emerging from Arab Spring Revolutions,' 159-169.

165 Guellali, 'The Constitution-Making Process in Tunisia,' The Carter Center, http:// www.cartercenter.org, accessed on 30 October 2018.

166 Article 6 of the Tunisian Constitution of 2014.

167 Shaqoura \& Kristiansen, 'Islam and Human Rights: The Constitutional Debate in Tunisia.'

168 Bousbih \& Yaalaoui, 'The Interplay of Politics and Religion in the New Tunisian Constitution: A Legal Analysis,' in The Tunisian Constitutional Process: Main Actors and Key Issues (Duisburg, Germany: Global Dialogues, 2015), 16-23. 
or weak case for religious representation in state affairs they are intended to awaken us that the progression towards liberal democracy is a continuing process and the various religious permutations which can be uncovered. ${ }^{169}$

In 2010, a report by the Venice Commission ${ }^{170}$ comments that blasphemy is a recognised offence in Austria, Denmark, Finland, Greece, Italy, Lietchenstein, the Netherlands as well as San Marino, and that the penalty incurred for the above is usually a term of imprisonment (ranging from three to six months) with a two year sentence for malicious blasphemy in Greece. In countries such as Andorra, Cyprus, the Czech Republic, Denmark, Spain, Finland, Germany, Greece, Iceland, Italy, Lithuania, Norway, the Netherlands, Poland, Portugal, the Russian Federation, the Slovak Republic, Switzerland, Turkey, and the Ukraine, recognise insult as an offence. ${ }^{171}$ In 2007 in its Recommendation 1805, the Parliamentary Assemble of the Council of Europe commented that; "With regard to blasphemy, religious insult and hate speech against persons on the ground of their religion, the state is responsible for determining what should count as criminal offences within the limits imposed by the case law of the European Court of Human Rights. ${ }^{172}$

In the judgement of I. A. v Turkey 2005 (42571/98), ${ }^{173}$ the European Court of Human Rights ruled that the Turkish authorities had not violated the right to freedom of expression when it convicted a publisher for producing material insulting to Prophet Muhammad and the Holy Qu'ran. The court in this instance had to weigh the right of the plaintiff to free expression against

169 Böckenförde, 'The Dynamics of Comprehensive Constitution-building: Religion and the Concept of Twin Tolerations in Tunisia,' 24-35.

170 Venice Commission, 'Blasphemy, Insult and Hatred: Finding Answers in a Democratic Society,' Science and Technique of Democracy Series, no. 47 (Strasbourg: Council of Europe, 2010), 19. Co-operation between the Venice Commission and the Southern Mediterranean countries started before the Arab spring. Algeria and Morocco became full members in 2007, and Tunisia in 2010. The Venice Commission co-operates with countries of the Southern Mediterranean region in areas such as, democratic institutions and fundamental rights, constitutional justice and ordinary justice, and elections, referendums and political parties.

171 In Germany and Portugal, a legal disturbance of the peace must also have been caused for the relevant action to qualify as an offence.

172 Böckenförde, 'The Dynamics of Comprehensive Constitution-building: Religion and the Concept of Twin Tolerations in Tunisia,' 24-35.

173 A. I v. Turkey 2005 (42571/98) European Court of Human Rights, http://hudoc. echr.coe.int, accessed on 27 October 2018. 
the right of others to have their freedom of thought, conscience, and religion respected. The court came to the realisation that certain passages did indeed constitute an abusive attack on the primary sources of Islam. From a Western perspective, according to Stepan, a legal scholar, as late as 1995, all mature democracies in Western Europe in which Lutheranism was the dominant faith had an established church (Sweden, Denmark, Finland and Norway). ${ }^{174}$

In the United Kingdom, the monarch is the Supreme Governor of the Church of England. Twenty six seats in the UK parliament's second chamber are reserved to Anglican bishops. ${ }^{175}$ By constitutional design and due to his/her role in the appointment process of the two most senior archbishops within the Church of England, the Prime Minister should not be perceived as processing bias against the established church. ${ }^{176}$ The drafters of the Malta constitution ${ }^{177}$ a country no more than 300km's from Tunisia, contains the following provisions in its constitution, "The religion of Malta is the Roman Catholic Apostolic Religion. The authorities of the Roman Catholic Apostolic Church have the duty and the right to teach which principles are right and wrong. Religious teaching of the Roman Catholic Apostolic Faith shall be provided in all State schools as part of compulsory education". ${ }^{178}$

Surprisingly, these constitutional provisions, Malta was considered to meet the criteria for accession to the European Union (the Copenhagen criteria), one of which is 'stability of institutions guaranteeing democracy, the rule of law, human rights and respect for as well as the protection of minorities. ${ }^{179}$

174 Stepan, 'Tunisia's Transition and the Twin Tolerations,' Journal of Democracy (2012): 89-103.

175 Böckenförde, 'The Dynamics of Comprehensive Constitution-building: Religion and the Concept of Twin Tolerations in Tunisia,' 24-35.

176 Böckenförde, 'The Dynamics of Comprehensive Constitution-building: Religion and the Concept of Twin Tolerations in Tunisia,' 24-35. Under the Roman Catholic Relief Act of 1829, section 17, and the Jews Relief Act of 1858, section 4, no Roman Catholic or Jew may advise the sovereign on ecclesiastical matters. In an individual of either of these religious faiths were to occupy the office of Prime Minister, the ecclesiastical appointment procedure might therefore need to be adjusted.

177 Article 2 of the Malta Constitution, states the following: 2. (1) "The religion of Malta is the Roman Catholic Apostolic Religion", see also articles 2(2) and (3).

178 Article 2 of the Malta Constitution.

179 Böckenförde, 'The Dynamics of Comprehensive Constitution-building: Religion and the Concept of Twin Tolerations in Tunisia,' 24-35. 


\section{CONCLUSION}

Three years after the Jasmin Revolution and several drafts later, the Tunisian National Constituent Assembly (NCA) adopted an all-embracing constitutional text, accommodating the divergent Tunisian views while at the same time lending itself largely to a coherent interpretation. For the Tunisian people the path to constitutionalism proper is in its early stages and it up to society as well as the relevant institutions to concretise what they have accomplished so far and to begin era of constitutionalism founded on the constitutional text. From an international perspective the international actors can assist the Tunisian people towards progression of constitutionalism. In addition, the international actors and activists can lend support to domestic actors as well as to reflect on the experiences of the European experiences. As the European examples mentioned above has shown that it is quite possible that constitutional provisions reflecting religious and cultural identities of a country to be included in a constitution which in turn may form part of a constitutionalist disposition, without prejudice to democracy, the rule of law, human rights and/or respect of minorities.

\section{REFERENCES}

Abdesselem, 'The Making of A Constitution: A Look back at Tunisia's Thorny Consensus-Building Process,' http://www.constitutionnet.org, accessed on 26 October 2018.

Albertyn, 'Towards Substantive Representation: Women and Politics in South Africa,' in Women Making Constitutions: New Politics and Comparative Perspectives, ed. Alexandra D \& Hart V (London: Palgrave Macmillan, 2003), 99-117.

Al-Sharmani, Recent Reforms in Personal Status Laws and Women's Empowerment: Family Courts in Egypt (Egypt: The American University in Cairo Social Research Center, 2007).

Angrist, 'The Expressions of Political Dissent in the Middle East: Turkish Democratization and Authoritarian Community in Tunisia,' Comparative Studies in Society and History, vol. 41, no. 4 (1999): 730-757.

Arieff, 'Political Transition in Tunisia Congressional Research Service Report for Congress,' http://www.refwold.org, accessed on 14 October 2018.

Aswad, 'The Role of Religion in Constitutions Emerging from Arab Spring Revolutions,' Georgetown Journal of International Affairs, vol. 16, no. 1 (2015): 159-169. 
BBC News, 'The Tunisian President Fouad Mebazza Calls Election,' http:// www.bbc.co.uk/news/world-middle-east, accessed on 10 October 2018.

Böckenförde, 'The Dynamics of Comprehensive Constitution-building: Religion and the Concept of Twin Tolerations in Tunisia,' The Tunisian Constitutional Process: Main Actors and Key Issues, ed. Mathieu Rousselin \& Christopher Smith (Duisberg: Käte Hamburger Kolleg / Centre for Global Cooperation Research, 2015), 24-35.

Boulby, 'The Islamic Challenge: Tunisia since Independence,' Third World Quaterly, vol. 10, no. 2 (1998): 590.

Bousbih \& Yaalaoui, 'The Interplay of Politics and Religion in the New Tunisian Constitution: A Legal Analysis,' in The Tunisian Constitutional Process: Main Actors and Key Issues (Duisburg, Germany: Global Dialogues, 2015), 16-23.

Brandt, 'Constitutional-Making and Reforms: Options for the Process,' http:// constitutionalmakingforpeace.org, accessed on 19 October 2018.

Charfi, Islam and Liberty: The Historical Misunderstanding (London: Zed Books, 2005).

Charrad MM, 'Policy Shifts: State, Islam, and Gender in Tunisia, 1930s-1990s,' Social Politics (1997): 284-319.

Charrad, 'Tunisia at the Forefront of the Arab World: Two Waves of Gender Legislation,' Washington and Lee Law Review, vol. 64, no. 4 (2007): 1513.

Chusanayaini, 'Dynamics of Tunisian Polygamy Law in Gender Perspective,' media.netli.com, accessed on 2 May 2020.

Croitoru, 'Controversy Surrounding the Al-Zaytuna in Tunis: The Ambivalent Revival of Islamic Traditions,' http://en.qatana.de, accessed on 17 January 2019.

David "The Dark Ages of Islam: Ijtihad, Apostacy, and Human Rights in Contemporary Islamic Jurisprudence" Washington and Lee Journal of Civil Rights and Social Justice (2003)

De Silva de Alwis, Mnasri \& Ward, 'Women and the Making of the Tunisian Constitution,' http://acholarship.law.upenn.edu, accessed on 19 October 2017.

Dewey, Kaden, Marks, Matsushima \& Zhu, 'The Impact of Social Media on Social Unrest in the Arab Spring,' http://www.publicpolicystanford., accessed on 5 January 2019. 
El-Sayed, 'Post-Revolution Constitutionalism: the Impact of Drafting Process on the Constitutional Documents in Tunisia and Egypt,' Electronic Journal of Islamic and Middle Eastern Law, vol. 2 (2014): 39-62.

Entilis, 'Reformist Ideaology in the Arab World: The Case of Tunisia and Lebanon,' The Review of Politics, vol. 37, no. 4 (1975): 513-546.

Feuer, 'Islam and Democracy in Practice: Tunisia's Ennahda Nine Months,' http://brandeis.edu, accessed on 20 October 2018.

Geneva International Centre for Justice, 'Tunisia's UPR-2017 (conferencesmeetings/upr-sessions/ 1070-tunisia-s-upr-2017),' http://www.gicj.org/ oppositions-opinions, accessed on 19 October 2018.

Guellali, 'The Constitution-Making Process in Tunisia,' The Carter Center, http://www.cartercenter.org, accessed on 30 October 2018.

Habous Encyclopedia.com, http://www.encyclopedia.com, accessed on 5 January 2019.

Hourani, A History of the Arab Peoples (United Kingdom: Farber \& Farber, 2013).

Karray, 'The National Constituent Assembly, Historical Lessons and Contemporary Stakes,' Right to Nonviolence Tunisia Constitutional E-Forum, http://www.rightononviolence.org/mecf/mr-bassem-karray, accessed on 19 October 2018.

Khalfoune T Le Domaine Public Et Le Trust (2005) Revue internationale de droit comparé, vol. 57 no. 2 (2005): 441-470.

Khalil, 'Tunisia's Women: Partners in Revolution,' Journal of North African Studies, vol. 19, no. 2 (2014): 186-199.

Majalla's Notes, 'Islamism in the Maghreb: Taming Islamists by Integrating Them Into the Political System,' http://facebook.com, accessed on 26 September 2018.

Marsad, http://www.marsad.tn/fr/, accessed on 3 October 2018.

Mashour, 'Islamic Law and Gender Equality: Could There Be A Common Ground?: A Study of Divorce and Polygamy in Sharia Law and Gender Equality,' Human Rights Quarterly, vol. 27, no. 2 (2005): 562-596.

Micaud, 'Tunisia's Foreign Policy: Independence and Development,'Africa Today: African Non-Alignment and Foreign Policies, vol. 15, no. 6 (1968-1969) 12-15.

Morse \& Sayeh, 'Tunisia: Marriage, Divorce, and Foreign Recognition,' Family Law Quarterly, vol. 29, no. 3 (1995): 39-62. 
Murphy, 'Constitutional Rights Discourse: Canadian and South African Feminist Engagements,' in Women Making Constitutions: New Politics and Comparative Perspectives, ed. Alexandra D \& Hart V (London: Palgrave Macmillan, 2003), Pages 1-218.

Nouira, 'Obstacles on the Path of Tunisia's Democratic Transformation,' CarnegieEndowmentforInternationalPeace, http://carnegieendowment. org, accessed on 12 October 2018.

Office of the United Nations High Commissioner for Human Rights (OHCHR), 'Report of the OHCHR Assessment Mission to Tunisia 26 January 2011 to 2 February 2011,' http://www.ohchr.org/encountries/menaregions, accessed on 19 October 2018.

Omri, 'The Status of Women under Tunisian Law,' Journal of Policy Studies, vol. 18 (2004): 147-161.

Proctor \& Moussa, 'The Tunisian Constituent Assembly's By-laws: A Brief Analysis,' http://www.ndi.org, accessed on 30 September 2018.

Rehman "The Sharia, Islamic Family Laws and International Human Rights Law: Examining The Theory And Practice of Polygamy and Talaaq" International Journal of Law, Policy and the Family” (2007)

Salem, 'Tunisia,' www. freedomhouse.org, accessed on 3 January 2019.

Schäfer, 'The Tunisian Transition: Torn Between Democratic Consolidation and Neo-Conservatism in an Insecure Regional Context,' European Institute of the Mediterranean, http://www.die-gdi.ide, accessed on 19 October 2018.

Shaqoura \& Kristiansen, 'Islam and Human Rights: The Constitutional Debate in Tunisia,' The Danish Institute for Human Rights, http:// www. humanrights.dk, accessed on 16 October 2018.

Shults, 'Tunisia: Democracy and Islam in post-Arab Spring Politics,' http:// scholar.utc.edu/honors-thesis, accessed on 13 October 2018.

Stepan, 'Tunisia's Transition and the Twin Tolerations,' Journal of Democracy (2012): 89-103.

Suliman, 'The First Political Systems in the Independent Maghrib: A Comparative Study,' http://www.iua.edu.sd, accessed on 20 September 2018.

Tais, 'Islamic Perspectives in Post-revolutionary Tunisia,' Journal of Religion \& Society, vol. 17 (2015): 1-12. 
Tamaru, Holt-Ivry \& O’Reilly, 'Beyond Revolution: How Women Influenced Constitution Making in Tunisia,' http:// www.inclusivesecurity.org, accessed on 19 October 2018.

The Carter Center, 'The Carter Congratulates Tunisia's National Constituent Assembly on Final Draft of Constitution and Urges Safeguards for Human Rights,' http://cartercenter.org, accessed on 2 October 2018.

The Role of Islamic Law in Tunisia's Constitution and Legislation, http:// www.loc.gov/law/help/tunisia.php, accessed on 9 October 2018.

Venice Commission, 'Blasphemy, Insult and Hatred: Finding Answers in a Democratic Society,'Science and Technique of Democracy Series, no. 47 (Strasbourg: Council of Europe, 2010).

Warren, 'Lifting The Veil: Women and Islamic Law,' Cordoza Journal of Law \& Gender (2008): 1-33.

Zeghal, 'The Implicit Sharia: Established Religion and Varieties of Secularism in Tunisia,' in Varieties of Religious Establishment, ed. Winnifred Fallers Sullivan \& Lori G. Beaman (London: Ashgate, 2013), 107-130.

Zoglin, 'Tunisia at a Crossroads: Drafting a New Constitution,' American Society of International Law, vol. 17, no. 18 (2013), 1-19.

\section{Constitutions}

Constitution of Malta 1964

Constitution of Tunisia 2014

Constitution of Tunisia 1959

Constitution of Tunisia 1861

Pacte de Fondamental 1856

\section{International Statutes}

Roman Catholic Relief Act of 1829

Jews Relief Act of 1858

The Tunisia Code of Personal Status of 1956

The Venice Commission of 2020

United Nations Human Rights Office of The High Commission 
Universal Declaration of Human Rights, GA Res 217A(III), GOAR $3^{\text {rd }}$ Session, Resolutions, (Part 1) UN Doc A/810, adopted 10 December 1948.

International Covenant on Civil and Political Rights, GA Res 2200 (XXI), UN GAOR $21^{\text {st }}$ Session, Supp No 16, UN Doc A/6316 (1996) UNTS 171, adopted 16 December 1966.

\section{Case Law}

A. I v. Turkey 2005 (42571/98) European Court of Human Rights, http:// hudoc.echr.coe.int, accessed on 27 October 2018. 
Jurnal Syariah, Jil. 28, Bil. 2 (2020) 293-332 